Review Article

\title{
Longevity of resin composite restorations
}

\author{
Shisei Kubo
}

Address: Center for Clinical Education and Training, Nagasaki University Hospital, 1-7-1, Sakamoto, Nagasaki 852-8588, Japan

Running title: Longevity of resin composite restorations

Scientific field: Operative dentistry

\section{Corresponding author:}

Name: $\quad$ Shisei Kubo

Address: Center for Clinical Education and Training, Nagasaki University Hospital, 1-7-1, Sakamoto, Nagasaki 852-8588, Japan

Phone: $\quad 81-95-819-7757$

Fax: $\quad 81-95-819-7757$

E-mail: kubo@net.nagasaki-u.ac.jp 


\title{
Longevity of resin composite restorations
}

\begin{abstract}
In daily practice, an evidence-based approach is becoming more expected of dentist. However, only outcomes obtained from clinical studies are accepted as evidence. Although many clinical trials have been performed, most of them are short-term studies, whereas long-term studies are likely to provide more reliable evidence. In this article, prospective studies and retrospective longitudinal clinical studies on resin composite restorations were systematically searched with PubMed for literature in English and with Japana Centra Revuo Medicina (Ichushi Web) for articles in Japanese. Finally, 21 long-term (8 years or more) prospective studies and nine retrospective studies with survival analysis were selected and reviewed from more than 561 papers. The overall findings suggest that at least $60 \%$ of resin composite restorations will last more than 10 years when proper materials are applied correctly. Patient-, operator-, material- and tooth-related factors may have an influence on the survival of resin composite restorations. Appropriate maintenance policies based on MI concepts are claimed to enhance the longevity of resin composite restorations.
\end{abstract}

Keywords: Longevity; Resin composite; Long-term; Prospective study; Retrospective longitudinal study; Survival analysis 


\section{Introduction}

It is of interest and important for patients, dentists and funding agencies to know the longevity of dental restorations [1,2]. In addition, there has been an increasing emphasis on an evidence-based approach to clinical care and treatment since the middle of the 1990s [1]. Laboratory studies produce meaningful results for relatively short periods of time and can also evaluate the effect of a single variable, while keeping all other variables constant. However, laboratory studies do not always reflect the clinical behavior of the material because of the differences between laboratory and clinical conditions [3]. Therefore, Evidence-Based Medicine accepts outcomes obtained from clinical studies only as evidence.

If many long-term randomized controlled trials of resin composite restorations had been performed, a high level of evidence for their longevity would be available $[1,2,4]$. At present, longevity of restorations is estimated by three kinds of clinical study: a prospective study [5-25]; a retrospective longitudinal study with censored cases [26-33]; and a retrospective cross-sectional study on failed restorations only (without censored cases) [34-39]. Although the prospective studies can provide more reliable evaluation than the retrospective studies, prospective clinical trials are limited in number since they require many years with regular recalls in order to achieve sufficient clinical validation. During this period, restorative materials used will probably be replaced by successors or unavailable. In addition, the prospective studies may not reflect the real-life of restorations in general dental 
practice or daily living since they include many biases such as operator- and patient-related factors $[1,7,29,30,35]$. This is supported by the fact that secondary caries rarely occurred in the prospective cohort studies [5,9,12-14,19,21-25] though it is the principal reason for failure of restorations in daily general practice [29-39]. Retrospective studies are less defined than prospective ones, however, certain advantages of the retrospective studies are that many restorations can be examined in a relatively short time and more clinicians and patients are involved [30,35]. This may compensate for possible flaws and failures due to the method of data acquisition. Therefore, Mjör et al. [35-37] retrospectively investigated the longevity of failed restorations with an attempt to reflect a real-life situation. The lack of censored cases in such studies may mitigate against an accurate estimate the longevity of restorations. Survival analysis can deal with censored cases and estimate survival rates of restorations at a given time. Another advantage of survival analysis is that it does not require a simultaneous entry time for participants. In addition, a multivariate survival analysis can evaluate the effect of two or more metric and/or nonmetric variables on survival.

The purpose of this article is to provide a review of long-term ( 8 years or more) prospective and retrospective studies with censored cases of resin composite restorations, and to investigate factors contributing to their longevity.

\section{Search methods for identification of studies and their results}

\subsection{Electronic searches}


Systematic searches were carried out with PubMed for literature in English and with Japana Centra Revuo Medicina (Ichushi Web) for literature in Japanese on January 1 in 2010. The searches covered the 20-year period of 1990-2009. Search strategies are given in Table 1,2 and 3.

\subsection{Searching references of the selected articles}

A search of references in the selected articles for other eligible articles was made.

\subsection{Inclusion criteria}

The inclusion criteria were longitudinal studies on clinical performance of resin composite restorations placed in permanent teeth over 8 years or more. Studies presented at academic meetings, the full texts of which had not yet been published in any journals, were also included. Selection was done by the author alone.

\subsection{Results}

Four hundred and three prospective studies and 26 retrospective studies in English for potential inclusion in the review were retrieved from the PubMed electronic search. With respect to the 132 articles retrieved from Ichushi Web, if the articles were published as original articles in academic journals, their abstracts were available. After reading all titles and/or abstracts, and applying the inclusion criteria, 21 prospective studies [5-25] and six retrospective studies remained for review [26-31]. Two retrospective studies presented at academic meetings were also included [32,33]. In addition, one 10-year retrospective study 
with a small sample size, the survival rates of which were calculated by descriptive statistics, was included as it was performed in Japan [40].

\section{Prospective studies}

Survival rates of resin composite restorations obtained from the long-term prospective studies using the descriptive statistics, potential factors in longevity, such as patient, operator, materials, cavity factors, etc., and main reasons for replacement are summarized in Table 4. More than 10-year (10 and 17 years) survival rates of Class I restorations ranged from $69.4 \%$ to $100 \%$ in 3 clinical trials $[8,18,19]$, however, it must be noted that the $100 \%$ was obtained from the very small sample size $(n=4)$. Around 10-years (4.8 -17 years) survival rates of Class II restorations ranged from $58.3 \%$ to $100 \%$ in 9 clinical trials $[8,10,12,15,17-21]$. Survival rates of combined Class I and II restorations calculated from four studies varied from $40 \%$ to $86.3 \%[11,13,14,16]$. With respect to the survival rate of Class III restorations, five studies provided the rates ranged between $73 \%$ and $100 \%[6-9,19]$. No information about Class IV restorations was available. A large number of clinical trials of resin composite restorations in non-carious cervical lesions (Class V) have been performed. However, long-term data from well designed studies have not been published until recently. Survival rates of Class $\mathrm{V}$ restorations obtained from six studies showed a wide range of between $5.3 \%$ and $100 \%$ [8,19,22-25]. Depending on restorative materials and patient's characteristics, overall findings indicate 10 -year survival rates of $70 \%$ or more, regardless of cavity type. 


\section{Retrospective studies}

Four out of 6 studies were published in the last 3 years [29-31,40]. Although our retrospective study [28] was published in 2001, there were several possible shortcomings. Therefore, we have been improving the previous study design in order to provide more reliable and informative data $[32,33]$.

Ten-year survival rates of resin composite restorations estimated by survival analysis of the data obtained from the retrospective studies are given in Table 5. Potential factors in longevity, such as patient, operator, materials, cavity factors, etc., and main reasons for replacement are also tabulated. Ten-year survival rates of Class I restorations ranged between $59.9 \%$ and $67.8 \%[32,33,40]$. Ten-year survival rates of Class II restorations varied from $55.1 \%$ to $89.7 \%[30,32,33,40]$. Survival rates of Class I and II restorations ranged from $60.4 \%$ to $83.0 \%$ [28,29,31]. The lowest values were obtained from the restorations placed by inexperienced operators or general practitioners $[31,33]$. With respect to Class III, IV and V resin composite restorations, only one study [26] was published and it reported that 10-year survival rates were $72.0 \%$ for Class III, $56.3 \%$ for Class IV and $69.9 \%$ for Class V. In this study 2 circumstances should be noted. One is that many resin composite restorations back in old days would have been placed without enamel etching and bonding, and the other is that the patients attended regularly for check-ups and treatments for 25 years on average. According to our two studies [32,33], 10-year survival rates of Class III and V restorations 
ranged from $69.7 \%$ to $79.6 \%$ and from $56.4 \%$ to $89.3 \%$, respectively. Nikaido et al. [40] retrospectively investigated the 10-year clinical performance of resin composite restoration placed with the acid etch-technique in similar clinical circumstances to our studies, e.g., chair time, cavity preparation, restorative materials and patient characteristics. The results of their study seem to be comparable to ours.

\section{Failure modes in resin composite restorations}

For Class I and II restorations, caries was the dominant failure reason in four articles $[8,10,20,31]$, restoration fracture exceeded $50 \%$ in one paper [18], and caries and fracture were the main reasons for failure in 6 studies [11,15-17,29,33]. Opdam et al. [30] reported an interesting result that the dominant reason changed with restorative techniques; fracture for the cervical lining 'sandwich' technique, and caries for a total-etch technique. For Class III restorations, secondary caries was the main reason for failure in two studies $[6,33]$, but one paper indicated the very low incidence of secondary caries [9]. For Class V restorations, secondary caries was hardly detected in the selected studies $[8,9,19,22-25]$ except one study [33]. It should be noted that many clinical trials of resin composite restorations in non-carious cervical lesions have been performed in order to evaluate the effectiveness of adhesive systems. The failure mode of such restorations in non-carious cervical lesions may be different from those in carious lesions at the gingival third of the buccal or lingual surfaces. Cross-sectional studies, which may include restorations in both cervical caries and 
non-carious lesions, indicated that secondary caries and marginal discoloration were the main reasons for replacement $[34,36,38]$. These findings suggest that minimal intervention (MI) concepts [41], such as management of caries risk and monitoring clinical problems, enhance the longevity of restorations.

In our study [33], although 10-year survival rate of resin composite was estimated at $84.9 \%$ by the Kaplan-Meier statistic, the median longevity of the failed restorations was 2.8 years. With respect to posterior resin composite restorations, Gaengler et al. [16] discriminated the early failures (e.g., fracture and loss of filling material) from the late failures (e.g., approximal secondary caries), which is supported by other studies [33,37]. Opdam et al. [30] reported that most of the failures did not occur before 4 years of clinical service. Rodolpho et al. [18] demonstrated steep declines in survival curves after 10 years. For Class $\mathrm{V}$ restorations, Ritter et al. [24] reported substantial deterioration of clinical performance between 3-year and 8-year evaluations. Van Dijken et al. in their 13-year clinical studies $[22,23]$ observed various degradation patterns of the resin-dentin bond associated with adhesive systems. These findings indicate the necessity and importance of long-term clinical studies.

\section{Contributing factors}

It has been considered that the longevity of dental restorations is dependent upon many different factors including patient-, operator, materials- and tooth-related factors $[2,6,34,37]$. 
The effect of these factors on the longevity of resin composite restorations examined in the selected literatures and our studies [5-33,40] are summarized in Table 6.

\subsection{Patient-related factors}

\subsubsection{Gender and age at placement}

In the selected articles for the present review, no effects of gender or age on the survival rates were consistently found [29-32], except for one study [27]. It should be noted that the number of children, whose caries risk may be higher than other life stage (generation) [37], was very small in these articles [29-32]. Hawthorne and Smales [27] indicated that lower survival rates occurred when the restorations were placed in the 0-20-year and over 60-year age groups compared to 21-40-year and 41-60-year age groups. These findings may be related to higher rates of secondary caries, tooth fractures and root caries in the relevant groups.

\subsubsection{Caries risk and occlusion}

Opdam et al. [30] reported that a Cox regression analysis revealed a significant increase in the failure rate of the posterior resin composite restorations for high caries risk patients. Aoyama et al. [31] indicated that the longevity of restorations placed in posterior teeth was associated with the occlusal status, that is, the longevity was significantly shorter in patients with Eichner Indices B1, B2 and B3 compared to those with Index A. In our study [33], retreatment risk was objectively rated based on a clinical history referring to a previous report 
[42]: low (no restorations in the last 3 years), medium (one or two restorations in last 3 years) and high (three or more restorations in last 3 years). In addition, the retreatment risk was assumed to be constant from the beginning. There were significant differences in survival curves between high risk and others as shown in Figure 1.

\subsection{Operator-related factors}

\subsubsection{Experience (years since graduation)}

Experience may have an influence on skill and criteria for replacement [36,37,39]. The influence of experience on the longevity of resin composite restorations was studied in three selected articles and our study [27,29,30,32]. No consistent results were found even in similar studies $[29,30]$. The influence of experience varied between restorative techniques. These are probably because of the small numbers of operators. Another possible factor is the year while the operators in their dental schools since the material and technology in restorative dentistry have considerably changed during recent years.

\subsubsection{Skill and specialty}

It has been speculated that the operator's skill has a great effect on the longevity of restorations, and there seems to be no disagreement about this speculation. However, few clinical studies have been performed to verify this hypothesis [43]. In our study [33], there was a significant difference in 10-year survival rates between the author and the other 24 dentists (Figure 2). However, Cox proportional hazards model indicated no significant 
effects of experience or specialty (research fields and departments) on the survival function among 24 dentists.

\subsubsection{Criteria for replacement}

Criteria for replacement may have some effect on the longevity of resin composite restorations [9,29], as suggested by Browning and Dennison [34]. Unfortunately, standardized diagnostic criteria for replacement of restorations have not established yet. Although it is relatively easy to obtain agreement from each operator in the case of pulpitis, retention failure and fracture of restorations, it is more difficult to obtain agreement on secondary caries, marginal discoloration, moderate color mismatching, and composite wear [1,40]. Hawthorne and Smales [27] indicated that a change of dentist had no significant effect on restoration survival except for except resin composite restorations in which the change tended to show a positive effect. On the other hand, a survival analysis using an insurance claim database revealed that a change of dentist had a significant and negative effect on the longevity of restorations [44]. Modified or original United States Public Health Service (USPHS) criteria were used in 17 out of 21 prospective studies. Chadwick et al. [1] discussed the problems associated with outcome measures of restoration failures. In addition, USPHS criteria are not widely used in daily practice even at university hospitals, and not among general practitioners (at least in Japan), since evidence and consensus are still searched for the criteria for replacement. Deterioration of marginal integrity increased with 
time, but most restorations were evaluated still clinically acceptable [19,21,24,25]. There is an urgent need for development of reliable and more objective criteria for replacement of restorations based on evidence and MI concepts.

\subsection{Material-related factors}

\subsubsection{Adhesive systems}

Van Dijken et al. [22,23] have consecutively evaluated many adhesive systems using the same protocol, and reported that adhesive systems had a great influence on retention of resin composite in non-carious cervical lesions. In addition, they revealed a wide variation of dentin bonding effectiveness between the systems independent of adhesive category. These findings are supported by the results of a systematic review [4]. In the rest of the selected articles, however, no significant effects of adhesive systems on survival function were found. This is probably because resin composites show high and stable bonding to enamel etched with phosphoric acid, regardless of adhesive system. Another possible explanation is that only one or a few adhesives systems were used in the studies. Generally, products from Kuraray Medical, such as Clearfil Photo Bond, Liner Bond II and SE Bond, showed good clinical performances in many studies [4,5,12,17,19,22,28-30,32,33,40]. Our study [33] revealed that no significant difference in survival function between 2-step self-etch (mainly Clearfil Liner Bond II and SE Bond) and conventional total etch-and-rinse (Clearfil Photo Bond) systems up to 10 years (Figure 3). 


\subsubsection{Resin Composite}

For resin composites the influential factors on the survival are considered, fracture toughness, wear resistance, color stability and surface texture. Five articles demonstrated that the posterior resin composites used did not show significant differences in their survival rates $[11,12,17,18,29]$. However, two of these five studies reported significant effects of resin composites on clinical performance, such as marginal adaptation, marginal discoloration and wear resistance, within the clinically acceptable range [11,12]. Nordbø et al. [10] showed a possible effect of restorative materials on the longevity of Class II restorations. Lundin and Koch [14] indicated a significant difference in failure rates from 5 to 10 years between two experimental resin composites developed by the same manufacturer. The only difference in these two resin composites was the addition of barium aluminum silicate to make one of them radiopaque.

\subsubsection{Restorative technique}

Lindberg et al. [20] indicated no significant differences in 9-year survival rates of Class II restorations between hybrid resin composite restorations and open sandwich restorations, in which a polyacid-modified resin composite was placed as first layer in the cervical part of the cavity and following layers were placed with a resin composite. By contrast, Opdam et al. [30] reported that a total-etch technique showed a significantly higher 9-year survival rate of Class II restorations compared to a closed-sandwich technique in which a thin layer of 
resin-modified glass-ionomer lining cement was applied on the entire dentin surface. Wilder et al. [25] revealed that the 12-year clinical performance of a dual-cured adhesive was excellent and was not affected by dentin acid-etching. Qvist and Strøm [6] reported no significant difference in survival rates of Class III restorations at 11 years between restorative techniques, mainly with or without an enamel bevel.

\subsection{Tooth (cavity)-related factors}

\subsubsection{Class and cavity size (the amount of restored surfaces)}

With respect to the comparison between Class I and Class II restorations, there are inconsistent findings $[13,14,18,32,33,40]$. In addition, there are contradictory outcomes even in the articles, which demonstrated significant differences between cavity designs. Rodolpho et al. [18] reported that Class I resin composite restorations showed significant better survival function compared to Class II restorations, whereas Kubo et al. [33] indicated opposite results. In our earlier study [32], there were no significant differences in the longevity between Class I, II, III and V restorations. In the later study [33], however, significant differences were found between classes (Figure 4). Although the sample sizes of Class I restorations in both studies were markedly smaller compared to those of other classes, the later study may provide more reliable information since the relatively high recall rate of 91\% was obtained. Concerning the effect of cavity size, there are also inconsistent findings $[13,14,18,29,30]$. All three articles [18,29,30], which showed significant effects on 
longevity demonstrated that failure rates significantly increased with the number of the restored surfaces.

\subsubsection{Tooth type (premolars vs molars)}

Although three articles showed no significant effect of tooth type on the longevity of posterior resin composite restorations [10,13,31], four articles demonstrated that restorations placed in premolars showed significant better survival rates compared to those in molars $[15,17,18,30]$. This may be due to the greater occlusal forces on molar restorations compared to premolar restorations. Another possible explanation is poorer access to operating field in molars, and which may require more extensive restorations. Figure 5 shows survival curves of resin composite restorations by tooth type obtained from our data. The log-rank test indicated significant difference between premolars and molars, while the Cox proportional hazards model revealed no significant difference between them. Cox proportional hazards model allows analyzing the effect of several risk factors on survival and is useful to control for confounders due to multivariate analysis. Therefore, the results obtained from Cox proportional hazards model seems to be more reliable.

\section{Conclusions}

From the overall findings, it can be concluded that at least $60 \%$ of resin composite restorations would survive more than 10 years when proper materials are applied correctly. In addition, appropriate maintenance policies based on MI concepts are able to increase the 
longevity of resin composite restorations, and may result in the enhancement of general health of the patients.

\section{Acknowledgements}

The authors wish to thank Prof. Martin Tyas, University of Melbourne, for assistance in preparation of the manuscript. 


\section{References}

1. Chadwick B, Treasure E, Dummer P, Dunstan F, Gilmour A, Jones R, Phillips C, Stevens J, Rees J, Richmond S. Challenges with studies investigating longevity of dental restorations-a critique of a systematic review. J Dent 2001; 29: 155-161.

2. Manhart J, Chen HY, Hamm, Hickel R. Review of the clinical survival of direct and indirect restorations in posterior teeth of the permanent dentition. Oper Dent 2004; 29: 481-508.

3. Van Meerbeek B, De Munck J, Yoshida Y, Inoue S, Vargas M, Vijay P, Van Landuyt K, Lambrechts P, Vanherle G. Adhesion to enamel and dentin: current status and future challenges. Oper Dent 2003; 28: 215-235.

4. Peumans M, Kanumilli P, De Munck J, Van Landuyt K, Lambrechts P, Van Meerbeek B. Clinical effectiveness of contemporary adhesives: A systematic review of current clinical trials. Dent Mater 2005; 21: 864-881.

5. Fukushima M, Nakamata T, Tsukuda Y, Yuda J, Okamoto A, Iwaku M. Longevity of chemically-cured posterior composite restorations -10-year clinical observation-. Jpn J Conserv Dent 1993; 36: 331-340 (in Japanese with English abstract).

6. Qvist V, Strøm C. 11-year assessment of Class-III resin restorations completed with two restorative procedures. Acta Odontol Scand 1993; 51: 253-262.

7. Jokstad A, Mjör IA, Nilner K, Kaping S. Clinical performance of three anterior restorative materials over 10 years. Quintessence Int 1994; 25: 101-108. 
8. Shimizu T, Kitano T, Inoue M, Narikawa K, Fujii B. Ten-year longitudinal clinical evaluation of a visible light cured posterior composite resin. Dent Mater J 1995; 14:120-134.

9. Millar BJ, Robinson PB, Inglis AT. Clinical evaluation of an anterior hybrid composite resin over 8 years. Br Dent J 1997; 182: 26-30.

10. Nordbø H, Leirskar J, von der Fehr FR. Saucer-shaped cavity preparations for posterior approximal resin composite restorations: observations up to 10 years. Quintessence Int 1998; 29: 5-11.

11. Collins CJ, Bryant RW, Hodge KLV. A clinical evaluation of posterior composite resin restorations: 8-year findings. J Dent 1998; 26: 311-317.

12. Mair LH. Ten-year clinical assessment of three posterior resin composites and two amalgams. Quintessence Int 1998; 29: 483-490.

13. Raskin A, Michotte-Theall B, Vreven J, Wilson NHF. Clinical evaluation of a posterior composite 10-year report. J Dent 1999; 27: 13-19.

14. Lundin SA, Koch G. Class I and II posterior composite resin restorations after 5 and 10 years. Swed Dent J 1999; 23: 165-171.

15. Van Dijken JWV. Direct resin composite inlays/onlays: an 11 year follow-up. J Dent 2000; 28: 299-306.

16. Gaengler P, Hoyer I, Montag R. Clinical evaluation of posterior composite restorations: The 10-year report. J Adhes Dent 2001: 3: 185-194.

17. Pallesen U, Qvist V. Composite resin fillings and inlays. An 11-year evaluation. Clin Oral Invest 2003; 
7: 71-79.

18. da Rosa Rodolpho PA, Cenci MS, Donassollo TA, Loguércio AD, Demarco FF. A clinical evaluation of posterior composite restorations: 17-year findings. J Dent 2006; 34: 427-435.

19. Akimoto N, Takamizu M, Momoi Y. 10-year clinical evaluation of a self-etching adhesive system. Oper Dent 2007; 32: 3-10.

20. Lindberg A, van Dijken JW, Lindberg M. Nine-year evaluation of a polyacid-modified resin composite/resin composite open sandwich technique in Class II cavities. J Dent 2007; 35: 124-129

21. Gordan VV, Mondragon E, Watson RE, Garvan C, Mjör IA. A clinical evaluation of a self-etching primer and a giomer restorative material: results at eight years. J Am Dent Assoc 2007; 138: 621-627.

22. Van Dijken JWV, Sunnegårdh-Grönberg K, Lindberg A. Clinical long-term retention of etch-and-rinse and self-etch adhesive systems in non-carious cervical lesions. A 13 tears evaluation. Dent Mater 2007; 23: 1101-1107.

23. Van Dijken JWV, Pallesen U. long-term dentin retention of etch-and-rinse and self-etch adhesives and a resin-modifies glass ionomer cement in non-carious cervical lesions. Dent Mater 2008; 24: 915-922.

24. Ritter AV, Swift EJ Jr, Heymann HO, Sturdevant JR, Wilder AD Jr. An eight-year clinical evaluation of filled and unfilled one-bottle dental adhesives. J Am Dent Assoc 2009; 140: 28-37. 
25. Wilder AD Jr, Swift EJ Jr, Heymann HO, Ritter AV, Sturdevant JR, Bayne SC. A 12-year clinical evaluation of a three-step dentin adhesive in noncarious cervical lesions. J Am Dent Assoc 2009; 140: 526-535.

26. Smales RJ, Hawthorne WS. Long-term survival and cost-effectiveness of five dental restorative materials used in various classes of cavity preparations. Int Dent J 1996; 46: 126-130.

27. Hawthorne WS, Smales RJ. Factors influencing long-term restoration survival in three private dental practices in Adelaide. Aust Dent J 1997; 42: 59-63.

28. Kubo S, Nakasa R, Hayashi Y. Survival analysis of resin composite and cast restorations. Jpn J Conserv Dent 2001; 44: 802-809 (in Japanese with English abstract).

29. Opdam NJM, Bronkhorst EM, Rooters JM, Loomans BAC. A retrospective clinical study on longevity of posterior composite and amalgam restorations. Dent Mater 2007; 23: 2-8.

30. Opdam NJM, Bronkhorst EM, Rooters JM, Loomans BAC. Longevity and reasons for failure of sandwich and total-etch posterior composite resin restorations. J Adhes Dent 2007; 9: 469-475.

31. Aoyama T, Aida J, Takehara J, Morita M. Factors associated with the longevity of restorations in posterior teeth. J Dent Hlth 2008; 58: 16-24 (in Japanese with English abstract).

32. Kubo S, Yokota H, Hayashi Y. Longevity of resin composite restorations. J Dent Res 2006; 85 (Spec Iss B/CDrom). Abstr. No. 541.

33. Kubo S. Clinical bonding durability of resin composite restorations. Adhes Dent 2008; 26: 174 (in Japanese). 
34. Browning WD, Dennison JB. A Survey of failure modes in composite resin restorations. Oper Dent 1996; 21: 160-166.

35. Mjör IA. The reasons for replacement and the age of failed restorations in general dental practice. Acta Odontol Scand 1997; 55: 58-63.

36. Burke FJT, Cheung SW, Mjör IA, Wilson NHF. Restoration longevity and analysis of reasons for the placement and replacement of restorations provided by vocational dental practitioners and their trainers in the United Kingdom. Quintessence Int 1999; 30: 234-242.

37. Mjör IA, Dahl JE, Moorhead JE. Age of restorations at replacement in permanent teeth in general dental practice. Acta Odontol Scand 2000; 58: 97-101.

38. Tyas MJ. Placement and replacement of restorations by selected practitioners. Aust Dent J 2005; 50: 81-89.

39. Sunnegårdh-Grönberg K, Dijken JWV, Funegård U, Lindberg A, Nilsson M. Selection of dental materials and longevity of replaced restorations in public dental health clinics in northern Sweden. $\mathbf{J}$ Dent 2009; 37: 673-678.

40. Nikaido T, Takada T, Kitasako Y, Ogata M, Shimada Y, Yoshikawa T, Nakajima M, Otsuki M, Tagami J, Burrow MF. Retrospective study of the 10-year clinical performance of direct resin composite restorations placed with the acid-etch technique. Quintessence Int 2007; 38: 439.e240-246.

41. Tyas MJ, Anusavice KJ, Frencken JE, Mount G. Minimal intervention dentistry-a review. Int Dent J 2000; 50: 1-12. 
42. Caries diagnosis and risk assessment. A review of preventive strategies and management. J Am Dent Assoc 1995; 126 Suppl:1S-24S.

43. Nicolaisen S, von der Fehr FR, Lunder N, Thomsen I. Performance of tunnel restorations at 3-6 years. J Dent 2000; 28: 283-387.

44. Bogacki RE, Hunt RJ, del Aguila M, Smith WR. Survival analysis of posterior restorations using an insurance claims database. Oper Dent 2002; 27: 488-492. 
Figure 1

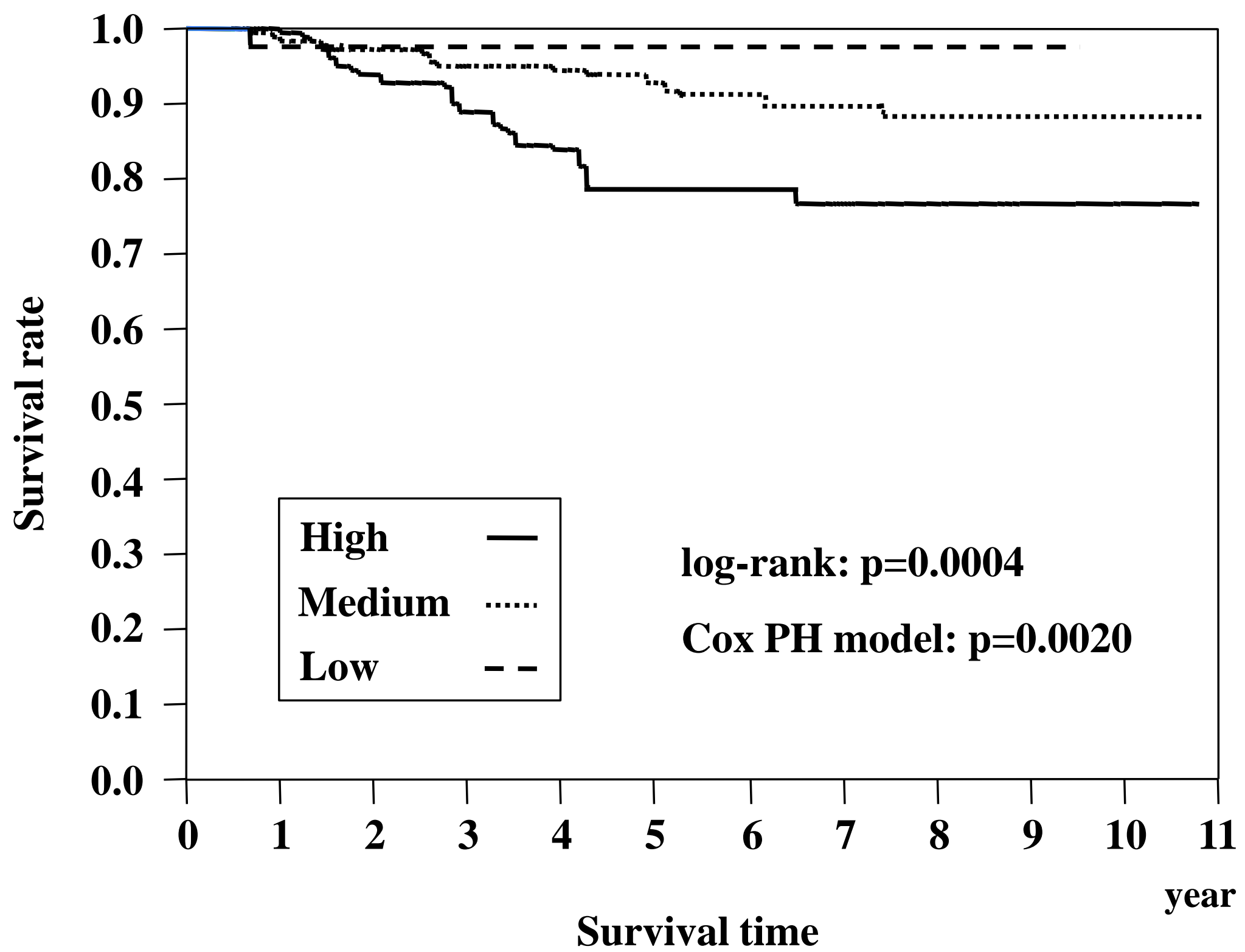


Figure 2

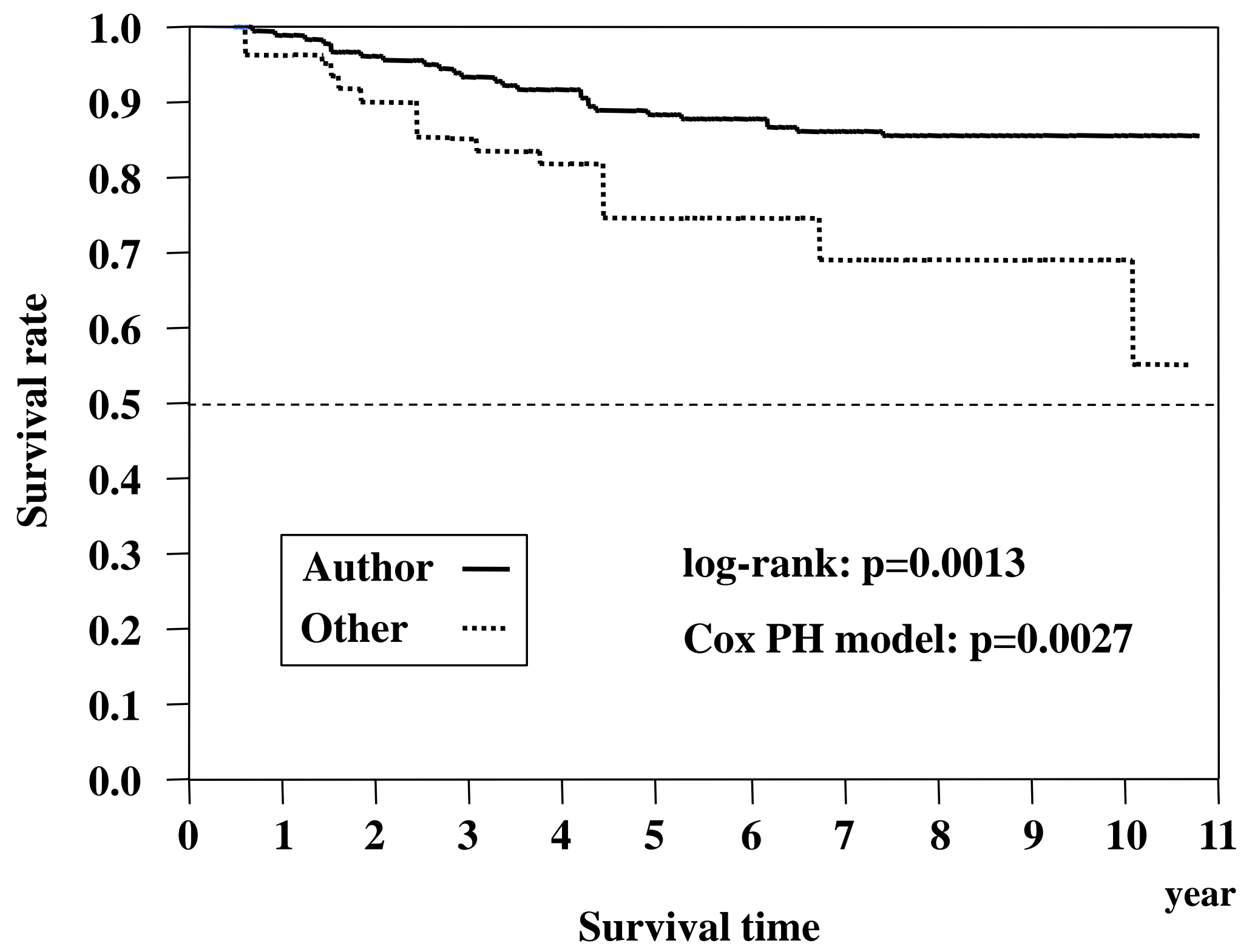


Figure 3

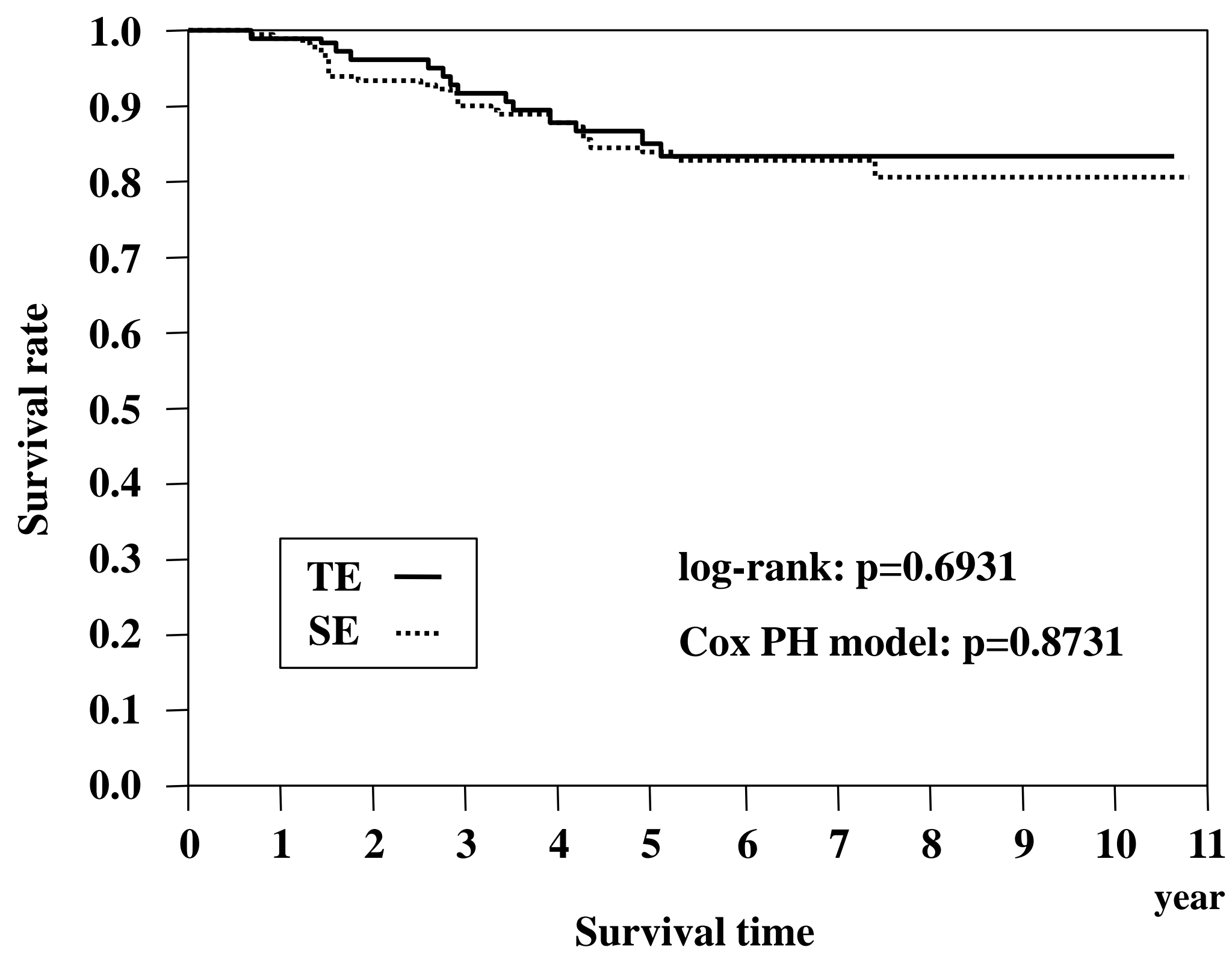


Figure 4

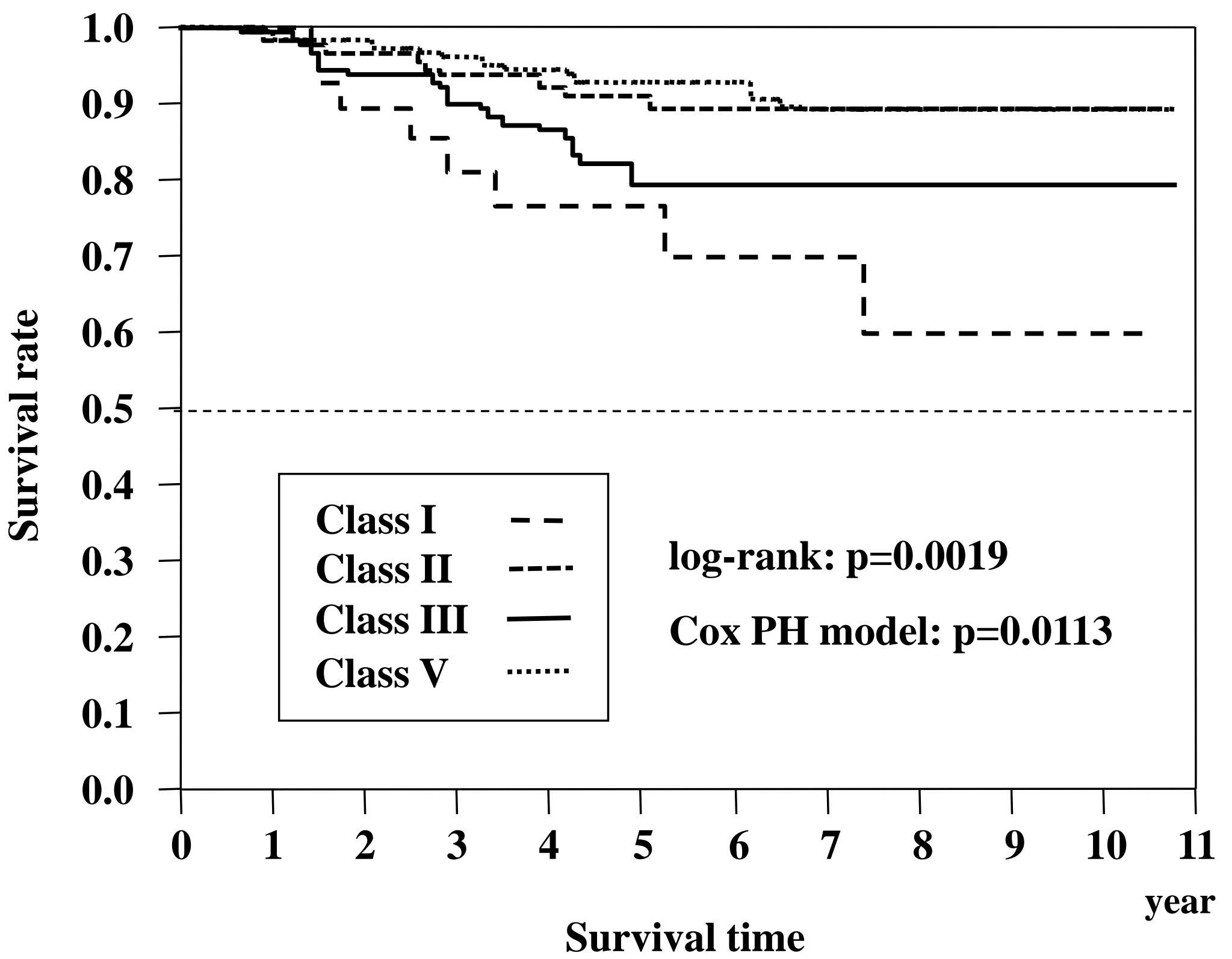


Figure 5

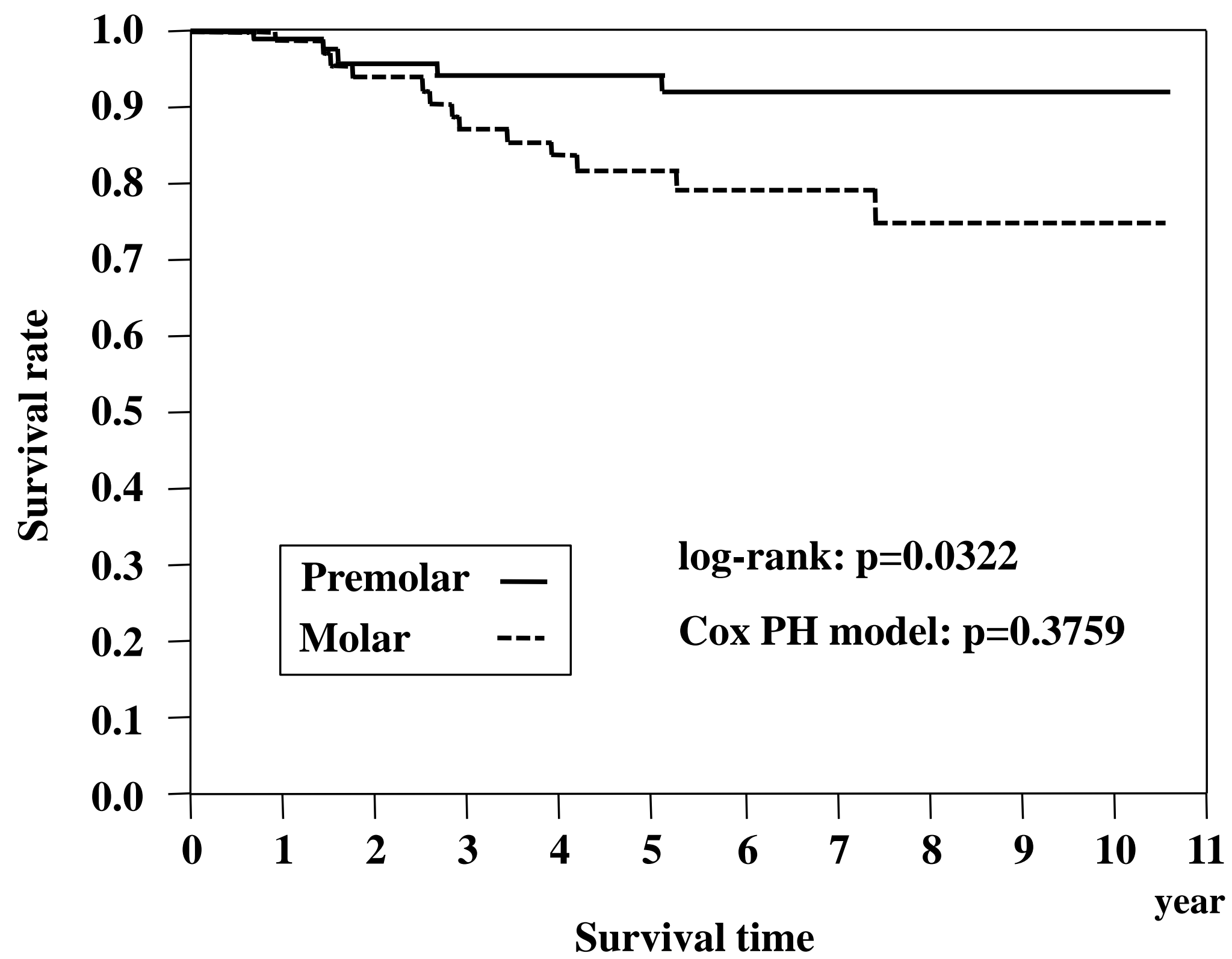




\section{Legends}

Figure 1 Survival curves of resin composite restorations by retreatment risk

A total of 479 Class I, II, III, and V resin composite restorations, which were placed by the author between 1995 and 2005, were analyzed. For the Cox proportional hazards model, gender, age at placement, retreatment risk, cavity design and adhesive system were included as covariates.

Figure 2 Survival curves of resin composite restorations by operator

A total of 416 Class I, II, III, and V resin composite restorations were placed with two-step self-etch systems by the author $(n=352)$ and the other 20 dentists $(n=64)$ between 1995 and 2005. For the Cox proportional hazards model, gender, age at placement, retreatment risk, cavity design and operator were included as covariates.

Figure 3 Survival curves of resin composite restorations by adhesive system

A total of 299 Class I, II and III resin composite restorations, which were placed two-step self-etch systems $(\mathrm{SE} ; \mathrm{n}=179)$ and conventional total etch-and-rinse (TE; 
$\mathrm{n}=120$ ) by the author between 1995 and 2005, were analyzed. For the Cox proportional hazards model, gender, age at placement, retreatment risk, cavity design and adhesive system were included as covariates.

Figure 4 Survival curves of resin composite restorations by class

A total of 479 Class I (33), II (128), III (138), and V (180) resin composite restorations, which were placed by the author between 1995 and 2005, were analyzed. For the Cox proportional hazards model, gender, age at placement, retreatment risk, cavity design and adhesive system were included as covariates.

Figure 5 Survival curves of resin composite restorations by tooth type

A total of 161 Class I and II resin composite restorations, which were placed in premolars (84) and molars (77) by the author between 1995 and 2005, were analyzed. For the Cox proportional hazards model, gender, age at placement, retreatment risk, cavity design, adhesive system and tooth type were included as covariates. 
Table1 Search strategy for prospective longitudinal studies on resin composite restorations in PubMed

$\# 1$ composite resin
$\# 2$ dentin-bonding agents
$\# 3$ \#1 or \#2
$\# 4$ dentistry, operative
$\# 5$ longitudinal studies
$\# 6$ follow-up studies
$\# 7$ prospective studies
$\# 8$ \#5 or \#6 or \#7
$\# 9$ \#3 and \#4 and \#8
$\# 10$ crowns
$\# 11$ dental abutments
$\# 12$ dentures
$\# 13$ dental porcelain
$\# 14$ pit and fissure sealants/therapeutic use
$\# 15$ tooth, deciduous
$\# 16$ tooth, nonvital
$\# 17$ root canal filling materials/therapeutic use
$\# 18$ tooth fractures/therapy
$\# 19$ \#10 or \#11 or \#12 or \#13 or \#14 or \#15 or \#16
or \#17 or \#18 or \#19
$\# 20$ \#9 not \#19
$\# 21$ (“1990”[Publication Date]: “2009” [Publication
Date]) Limits: Humans Sort by: Publication Date


Table 2 Search strategy for retrospective studies with survival analysis on resin composite restorations in PubMed

\#1 composite resins

\#2 dentistry, operative

\#3 retrospective studies

\#4 survival analysis

$\# 5$ \#1 and \#2 and \#3 and \#4

\#6 (“1990”[Publication Date]: "2009” [Publication

Date]) Limits: Humans Sort by: Publication Date 
Table 3 Search strategy for longevity of resin composite restorations in JCRM

$\# 1$ composite resins
$\# 2$ survival rate
$\# 3$ longevity
$\# 4$ long-term follow up
$\# 5$ clinical evaluation
$\# 6$ \#1 and \#2
$\# 7$ \#1 and \#3
$\# 8$ \#1 and \#4
$\# 9$ \#1 and \#5
$\# 10 \# 6$ or \#7 or \#8 or \#9
$\# 11$ primary tooth
$\# 12$ \#10 not \#11

JCRM: Japana Centra Revuo Medicina (Ichushi Web) 
Table 4 Survival rates of resin composite restorations obtained from long-term prospective studies using the descriptive statistics (\%)

\begin{tabular}{|c|c|c|c|c|c|c|c|c|c|c|c|c|c|c|}
\hline $\begin{array}{l}1^{\text {st }} \text { Author, } \\
\text { year [Ref.] }\end{array}$ & $\begin{array}{l}\text { Setting, } \\
\text { country }\end{array}$ & $\begin{array}{l}\text { Study } \\
\text { type }\end{array}$ & $\begin{array}{l}\text { No. of } \\
\text { patients }\end{array}$ & $\begin{array}{c}\text { Patient } \\
\text { mean age } \\
\text { and/or } \\
\text { range }\end{array}$ & $\begin{array}{c}\text { No. of } \\
\text { operators }\end{array}$ & $\begin{array}{l}\text { No. of } \\
\text { restorations } \\
\text { at baseline }\end{array}$ & Materials & $\begin{array}{l}\text { Criteria } \\
\text { for } \\
\text { evaluation }\end{array}$ & $\begin{array}{l}\text { Length of } \\
\text { follow up }\end{array}$ & $\begin{array}{l}\text { Recall } \\
\text { rates }\end{array}$ & Class & $\begin{array}{l}\text { Survival } \\
\text { rates }\end{array}$ & $\begin{array}{l}\text { Main reasons for } \\
\text { replacement }\end{array}$ & $\begin{array}{l}\text { Significant } \\
\text { factors }\end{array}$ \\
\hline $\begin{array}{l}\text { Wilder } \\
2009 \text { [25] }\end{array}$ & $\begin{array}{c}\text { University } \\
\text { USA }\end{array}$ & RCT & 53 & - & 6 & $\begin{array}{l}\text { EE: } 50 \\
\text { TE: } 50 \\
\text { All: } 100\end{array}$ & $\begin{array}{l}\text { OptiBond Dual } \\
\text { Cure; Herculite } \\
\text { XRV }\end{array}$ & $\begin{array}{l}\text { modified } \\
\text { USPHS }\end{array}$ & 12 & $\begin{array}{l}\text { EE: } 54 \\
\text { TE: } 38 \\
\text { All: } 46\end{array}$ & $\begin{array}{c}\mathrm{V} \\
\text { NCCLs }\end{array}$ & $\begin{array}{l}\text { EE: } 93 \\
\text { TE: } 84 \\
\text { All: } 89\end{array}$ & $\begin{array}{l}\text { retention failure, } \\
\text { No caries }\end{array}$ & $\begin{array}{l}\text { None (patient, } \\
\text { operator, lesion } \\
\text { characteristics) }\end{array}$ \\
\hline $\begin{array}{l}\text { Ritter } \\
2009[24]\end{array}$ & $\begin{array}{l}\text { University } \\
\text { USA }\end{array}$ & RCT & 33 & $\begin{array}{c}53 \\
27-77\end{array}$ & 7 & $\begin{array}{l}\text { OS: } 48 \\
\text { PB: } 51 \\
\text { All: } 99\end{array}$ & $\begin{array}{l}\text { OptiBond Solo } \\
\text { (OS), Prime \& } \\
\text { Bond } 2.1 \text { (PB); } \\
\text { Prodigy for OS, } \\
\text { TPH Spectrum for } \\
\text { PB }\end{array}$ & $\begin{array}{l}\text { modified } \\
\text { USPHS }\end{array}$ & 8 & $\begin{array}{l}\text { OS: } 60 \\
\text { PB: } 53\end{array}$ & $\begin{array}{c}\mathrm{V} \\
\text { NCCLs }\end{array}$ & $\begin{array}{l}\text { OS: } 70.8 \\
\text { PB: } 68.6\end{array}$ & $\begin{array}{l}\text { retention failure, } \\
\text { No caries }\end{array}$ & $\begin{array}{l}\text { None } \\
\text { (adhesives, } \\
\text { patient and } \\
\text { lesion } \\
\text { characteristics) }\end{array}$ \\
\hline $\begin{array}{l}\text { Van Dijken } \\
2008 \text { [23] }\end{array}$ & - & RCT & 88 & $\begin{array}{c}56.7 \\
28-83\end{array}$ & 1 & $\begin{array}{l}41-47 \text { for } \\
\text { respective } \\
\text { system } \\
\text { All: } 270\end{array}$ & $\begin{array}{l}\text { Opti Bond, } \\
\text { Permagen, } \\
\text { Scotchbond Multi- } \\
\text { Purpose, Syntac } \\
\text { classic, PSA, } \\
\text { Vitremer }\end{array}$ & $\begin{array}{l}\text { modified } \\
\text { USPHS }\end{array}$ & 13 & 79.6 & $\begin{array}{c}\mathrm{V} \\
\text { NCCLs }\end{array}$ & $13.2-64.4$ & $\begin{array}{l}\text { retention failure, } \\
\text { No caries }\end{array}$ & $\begin{array}{l}\text { adhesive } \\
\text { systems }\end{array}$ \\
\hline $\begin{array}{l}\text { Van Dijken } \\
2007 \text { [22] }\end{array}$ & $\begin{array}{l}\text { University } \\
\text { Sweden }\end{array}$ & RCT & 119 & $\begin{array}{c}54.5 \\
24-83\end{array}$ & 1 & $\begin{array}{l}43-57 \text { for } \\
\text { respective } \\
\text { system } \\
\text { All: } 337\end{array}$ & $\begin{array}{l}\text { Clearfil Liner } \\
\text { Bond, All Bond 2, } \\
\text { ART Bond, PUB 3, } \\
\text { Gluma 2000, } \\
\text { Denthesive; }\end{array}$ & $\begin{array}{l}\text { modified } \\
\text { USPHS }\end{array}$ & 13 & 81.6 & $\begin{array}{c}\mathrm{V} \\
\text { NCCLs }\end{array}$ & $5.3-73.7$ & $\begin{array}{l}\text { retention failure, } \\
\text { No caries }\end{array}$ & $\begin{array}{l}\text { adhesive } \\
\text { systems }\end{array}$ \\
\hline $\begin{array}{l}\text { Gordan } \\
2007 \text { [21] }\end{array}$ & $\begin{array}{c}\text { University } \\
\text { USA }\end{array}$ & PLS & 31 & $\begin{array}{c}34 \\
21-62\end{array}$ & 2 & $\begin{array}{l}\text { I : } 26 \\
\text { II: } 35 \\
\text { Total: } 51\end{array}$ & FL-Bond; Beautifil & $\begin{array}{l}\text { modified } \\
\text { USPHS }\end{array}$ & 8 & 67 & $\begin{array}{l}\text { I }\langle 16\rangle \\
\text { II }\langle 25\rangle\end{array}$ & 100 & $\begin{array}{l}\text { poor marginal } \\
\text { integrity but } \\
\text { clinically acceptable }\end{array}$ & None \\
\hline $\begin{array}{l}\text { Lindberg } \\
2007[20]\end{array}$ & $\begin{array}{c}\text { PDC } \\
\text { Sweden }\end{array}$ & RCT & 57 & $\begin{array}{c}34.6 \\
17-68\end{array}$ & 2 & $\begin{array}{l}75 \text { for each } \\
\text { group } \\
\text { All: } 150\end{array}$ & $\begin{array}{l}\text { Prime Bond 2.1; } \\
\text { Prisma TPH, open } \\
\text { sandwich (SW: } \\
\text { Dyract base) }\end{array}$ & $\begin{array}{l}\text { modified } \\
\text { USPHS }\end{array}$ & 9 & 90.0 & II & All: $90.7^{\#}$ & $\begin{array}{l}\text { 8/14: caries } \\
\text { 3/14: fracture }\end{array}$ & $\begin{array}{l}\text { None } \\
\text { (restorative } \\
\text { techniques) }\end{array}$ \\
\hline $\begin{array}{l}\text { Akimoto } \\
2007 \text { [19] }\end{array}$ & $\begin{array}{l}\text { University } \\
\text { Japan }\end{array}$ & PLS & 42 & - & 2 & 87 & $\begin{array}{l}\text { Clearfil Liner Bond } \\
\text { II; } 4 \text { resin } \\
\text { composites }\end{array}$ & $\begin{array}{l}\text { modified } \\
\text { USPHS }\end{array}$ & 10 & 51 & $\begin{array}{c}\text { I }<4> \\
\text { II }<2> \\
\text { III }<17> \\
\text { V }<19>\end{array}$ & 100 & $\begin{array}{l}\text { marginal } \\
\text { discoloration but } \\
\text { clinically acceptable }\end{array}$ & None \\
\hline
\end{tabular}
(the enamel, TE: etched both enamel and dentin, < >: number of restorations at final recall, ${ }^{*}$ age at the who attended the 8-year recall

\#: survival rates were estimated by the Kaplan-Meier method, life table analysis, or reading survival curves. ${ }^{\#}$ : resin composites were placed without an adhesive. 
Table 4 (continued) Survival rates of resin composite restorations obtained from long-term prospective studies using the descriptive statistics (\%)

\begin{tabular}{|c|c|c|c|c|c|c|c|c|c|c|c|c|c|c|}
\hline $\begin{array}{l}1^{\text {st }} \text { Author, } \\
\text { year [Ref.] }\end{array}$ & $\begin{array}{l}\text { Setting, } \\
\text { country }\end{array}$ & $\begin{array}{l}\text { Study } \\
\text { type }\end{array}$ & $\begin{array}{c}\text { No. of } \\
\text { patients }\end{array}$ & $\begin{array}{l}\text { Patient } \\
\text { mean age } \\
\text { and/or } \\
\text { range }\end{array}$ & $\begin{array}{l}\text { No. of } \\
\text { operators }\end{array}$ & $\begin{array}{l}\text { No. of } \\
\text { restorations } \\
\text { at baseline }\end{array}$ & Materials & $\begin{array}{l}\text { Criteria } \\
\text { for } \\
\text { evaluation }\end{array}$ & $\begin{array}{l}\text { Length of } \\
\text { follow up }\end{array}$ & $\begin{array}{l}\text { Recall } \\
\text { rates }\end{array}$ & Class & $\begin{array}{l}\text { Survival } \\
\text { rates }\end{array}$ & $\begin{array}{l}\text { Main reasons for } \\
\text { failure }\end{array}$ & $\begin{array}{l}\text { Significant } \\
\text { factors }\end{array}$ \\
\hline $\begin{array}{l}\text { Rodolpho } \\
2006 \text { [18] }\end{array}$ & $\begin{array}{l}1 \text { GDP } \\
\text { Brazil }\end{array}$ & $\mathrm{CCT}$ & 38 & $\begin{array}{l}42.5^{*} \\
(6.4)\end{array}$ & 1 & $\begin{array}{c}\text { I : } 75 \\
\text { II: } 207 \\
\text { Total: } 282\end{array}$ & $\begin{array}{l}\text { Scotchbond } 2 \text { \& P- } \\
\text { 50, Prime/XR Bond } \\
\text { \& Herculite XR }\end{array}$ & $\begin{array}{l}\text { modified } \\
\text { USPHS }\end{array}$ & 17 & - & $\begin{array}{l}\text { I at } 10 \mathrm{y} \\
\text { I at } 17 \mathrm{y} \\
\text { II at } 10 \mathrm{y} \\
\text { II at } 17 \mathrm{y}\end{array}$ & $\begin{array}{l}96^{\#} \\
55^{\#} \\
92^{\#} \\
20^{\#}\end{array}$ & $\begin{array}{l}\text { 53/98: fracture of resin } \\
\text { 16/98: tooth fracture } \\
\text { 22/98: caries }\end{array}$ & $\begin{array}{l}\text { tooth type, } \\
\text { cavity type, } \\
\text { cavity size }\end{array}$ \\
\hline $\begin{array}{l}\text { Pallesen } \\
2003 \text { [17] }\end{array}$ & $\begin{array}{l}\text { University } \\
\text { Denmark }\end{array}$ & RCT & 28 & $\begin{array}{c}35 \\
19-64\end{array}$ & 1 & $\begin{array}{l}\text { BD: } 28 \\
\text { EP: } 28 \\
\text { All: } 56\end{array}$ & $\begin{array}{l}\text { Gluma Prep } 2 \text { and } \\
\text { Clearfil New Bond; } \\
\text { Brilliant Dentin } \\
\text { (BD), Estilux } \\
\text { Posterior (EP) }\end{array}$ & $\begin{array}{l}\text { modified } \\
\text { USPHS }\end{array}$ & 11 & 96 & II & $\begin{array}{l}\text { BD: } 86 \\
\text { EP: } 74 \\
\text { All: } 84\end{array}$ & $\begin{array}{l}\text { 4/11: fracture of resin } \\
\text { 1/11: new caries } \\
\text { 2/11: secondary caries }\end{array}$ & tooth type \\
\hline $\begin{array}{l}\text { Gaengler } \\
2001[16]\end{array}$ & $\begin{array}{l}\text { University } \\
\text { Germany }\end{array}$ & PLS & 73 & $18-52$ & 4 & $\begin{array}{l}\text { I: } 115 \\
\text { II:79 } \\
\text { All:194 }\end{array}$ & $\begin{array}{l}\text { Ketac-Bond lining, } \\
\text { Universalbond; } \\
\text { Visio-Molar } \\
\text { radiopaque }\end{array}$ & CMP index & 10 & 32 & I \& II & 74.2 & $\begin{array}{l}\text { 5/16: secondary caries } \\
\text { 3/16: fracture of resin } \\
\text { 8/16: loss }\end{array}$ & None \\
\hline $\begin{array}{l}\text { Van Dijken } \\
2000 \text { [15] }\end{array}$ & $\begin{array}{l}\text { University } \\
\text { Sweden }\end{array}$ & СCT & 40 & $\begin{array}{c}48 \\
27-70\end{array}$ & 1 & 34 & $\begin{array}{l}\text { GC lining base, } \\
\text { enamel bonding } \\
\text { agent; Fulfil }\end{array}$ & $\begin{array}{l}\text { modified } \\
\text { USPHS }\end{array}$ & 11 & 97 & II & 72.7 & $\begin{array}{l}\text { 3/9: secondary caries } \\
\text { 4/9: fracture of resin } \\
\text { 2/9: wear }\end{array}$ & tooth type \\
\hline $\begin{array}{l}\text { Lundin, } \\
1999[14]\end{array}$ & $\begin{array}{l}\text { University } \\
\text { Sweden }\end{array}$ & CCT & $\begin{array}{c}65 \\
\text { dental } \\
\text { students }\end{array}$ & $\begin{array}{c}27 \\
15-45\end{array}$ & 2 & $\begin{array}{c}\text { I: } 45 \\
\text { II:92 } \\
\text { All: } 137\end{array}$ & $\begin{array}{l}\text { Experimental resin } \\
\text { composites (one is } \\
\text { Occlusin) }\end{array}$ & USPHS & 10 & 85.4 & I \& II & 79 & No secondary caries & materials \\
\hline $\begin{array}{l}\text { Raskin, } \\
1999 \text { [13] }\end{array}$ & $\begin{array}{l}\text { University } \\
\text { Belgium }\end{array}$ & PLS & $\begin{array}{c}36 \\
\text { dental } \\
\text { students }\end{array}$ & $\begin{array}{c}22.7 \\
19-40\end{array}$ & 1 & $\begin{array}{l}\text { I: } 42 \\
\text { II:58 } \\
\text { All: } 100\end{array}$ & $\begin{array}{l}\text { Dycal lining, } \\
\text { enamel bonding } \\
\text { agent; Occlusin }\end{array}$ & $\begin{array}{l}\text { modified } \\
\text { USPHS }\end{array}$ & 10 & 69 & I \& II & $40-50$ & $\begin{array}{l}\text { 10/23: occlusal wear } \\
\text { 7/23: proximal wear } \\
\text { 4/23: sensitivity } \\
\text { 2/23: caries }\end{array}$ & None \\
\hline $\begin{array}{l}\text { Mair, } \\
1998 \text { [12] }\end{array}$ & $\begin{array}{l}\text { University } \\
\text { England }\end{array}$ & CCT & $\begin{array}{c}\text { dental } \\
\text { students }\end{array}$ & - & 1 & $\begin{array}{l}30 \text { for each } \\
\text { composite } \\
\text { All: } 90\end{array}$ & $\begin{array}{l}\text { cement base, each } \\
\text { adhesive, Occlusin, } \\
\text { Clearfil Posterior, P- } \\
30\end{array}$ & - & 10 & 67 & II & 93.3 & No caries $(0 / 4)$ & materials \\
\hline
\end{tabular}


Table 4 (continued) Survival rates of resin composite restorations obtained from long-term prospective studies using the descriptive statistics (\%)

\begin{tabular}{|c|c|c|c|c|c|c|c|c|c|c|c|c|c|c|}
\hline $\begin{array}{l}1^{\text {st }} \text { Author, } \\
\text { year [Ref.] }\end{array}$ & $\begin{array}{l}\text { Setting, } \\
\text { country }\end{array}$ & $\begin{array}{l}\text { Study } \\
\text { type }\end{array}$ & $\begin{array}{l}\text { No. of } \\
\text { patients }\end{array}$ & $\begin{array}{l}\text { Patient } \\
\text { mean age } \\
\text { and/or } \\
\text { range }\end{array}$ & $\begin{array}{c}\text { No. of } \\
\text { operators }\end{array}$ & $\begin{array}{l}\text { No. of } \\
\text { restorations } \\
\text { at baseline }\end{array}$ & Materials & $\begin{array}{c}\text { Criteria } \\
\text { for } \\
\text { evaluation }\end{array}$ & $\begin{array}{l}\text { Length of } \\
\text { follow up }\end{array}$ & $\begin{array}{l}\text { Recall } \\
\text { rates }\end{array}$ & Class & $\begin{array}{l}\text { Survival } \\
\text { rates }\end{array}$ & Main reasons for failure & $\begin{array}{l}\text { Significant } \\
\text { factors }\end{array}$ \\
\hline $\begin{array}{l}\text { Collins } \\
1998[11]\end{array}$ & $\begin{array}{c}\text { PDC } \\
\text { Australia }\end{array}$ & CCT & 72 & $\begin{array}{l}16.8^{* * *} \\
13-32\end{array}$ & 1 & $\begin{array}{l}\text { more than } \\
80 \text { for each } \\
\text { group } \\
\text { All: } 330\end{array}$ & $\begin{array}{l}\text { cement lining; P-30 } \\
\text { (P3), Herculite XR } \\
\text { (HX), Heliomolar } \\
\text { (HM), Dispersalloy }\end{array}$ & $\begin{array}{l}\text { modified } \\
\text { Michigan } \\
\text { \& USPHS }\end{array}$ & 8 & 64.5 & I \& II & $\begin{array}{l}\text { HM: } 83.6 \\
\text { HX: } 84.6 \\
\text { P3: } 90.7 \\
\text { All: } 86.3\end{array}$ & $\begin{array}{l}\text { 8/25: secondary caries } \\
\text { 8/25: bulk fracture }\end{array}$ & materials \\
\hline $\begin{array}{l}\text { Nordb } \varnothing^{\# \#} \\
1998[10]\end{array}$ & $\begin{array}{l}\text { PDC } \\
\text { Norway }\end{array}$ & CCT & 37 & $13-17$ & 7 & $\begin{array}{l}\text { FF: } 34 \\
\text { OC: } 17 \\
\text { All: } 51\end{array}$ & $\begin{array}{l}\text { enamel bonding; Ful- } \\
\text { fil (FF), Occlusin } \\
(\mathrm{OC})\end{array}$ & USPHS & $4.8-9.6$ & 100 & II & $\begin{array}{l}\text { FF: } 59 \\
\text { OC: } 88 \\
\text { All: } 70\end{array}$ & $\begin{array}{l}\text { 8/16: caries } \\
\text { 4/16: poor adaptation }\end{array}$ & materials \\
\hline $\begin{array}{l}\text { Millar } \\
1997[9]\end{array}$ & $\begin{array}{l}\text { University } \\
\text { England }\end{array}$ & PLS & 24 & $\begin{array}{c}43 \\
16-70\end{array}$ & 3 & $\begin{array}{l}\text { III: } 25 \\
\text { V: } 16 \\
\text { All: } 44\end{array}$ & $\begin{array}{l}\text { Dycal lining, enamel } \\
\text { bonding resin; } \\
\text { Opalux }\end{array}$ & USPHS & 8 & 56.8 & III \& V & $73^{\#}$ & $\begin{array}{l}\text { one case was secondary } \\
\text { caries but the rest was } \\
\text { unclear }\end{array}$ & None \\
\hline $\begin{array}{l}\text { Shimizu } \\
1995[8]\end{array}$ & $\begin{array}{l}\text { University } \\
\text { Japan }\end{array}$ & CCT & 20 & $10-40$ & - & 91 & $\begin{array}{l}\text { experimental } \\
\text { adhesive; Lite-Fil P }\end{array}$ & $\begin{array}{l}\text { modified } \\
\text { USPHS }\end{array}$ & 10 & 100 & $\begin{array}{l}\text { I }\langle 49> \\
\text { II }<12> \\
\text { III }<9> \\
\text { V }<19>\end{array}$ & $\begin{array}{l}69.4 \\
58.3 \\
77.8 \\
94.7\end{array}$ & $\begin{array}{l}\text { 8/23: secondary caries } \\
\text { 8/23: new caries } \\
\text { 4/23: extraction }\end{array}$ & None \\
\hline $\begin{array}{l}\text { Jokstad } \\
1994[7]\end{array}$ & $\begin{array}{l}\text { GDP } \\
\text { Sweden }\end{array}$ & $\mathrm{CCT}$ & 57 & $\begin{array}{c}40 \\
9-72\end{array}$ & 1 & $\begin{array}{l}\mathrm{S}<66> \\
\mathrm{C}<28> \\
\mathrm{SC}<37> \\
\text { All: } 131\end{array}$ & $\begin{array}{l}\text { Dycal, enamel-etch } \\
\text { only, Concise (C), } \\
\text { Silar (S), Silicap } \\
\text { (SC) }\end{array}$ & USPHS & 10 & 73.3 & $\begin{array}{l}\text { III: } 112 \\
\text { IV: } 6 \\
\text { V: } 13\end{array}$ & $\begin{array}{l}\text { S: } 77^{\#} \\
\text { C: } 96^{\#}\end{array}$ & $\begin{array}{l}\text { Not clear, but secondary } \\
\text { caries and fracture seem } \\
\text { to be main reasons }\end{array}$ & materials \\
\hline $\begin{array}{l}\text { Qvist } \\
1993 \text { [6] }\end{array}$ & $\begin{array}{l}\text { University } \\
\text { Denmark }\end{array}$ & $\mathrm{RCT}$ & 35 & $\begin{array}{c}41 \\
24-65\end{array}$ & 1 & $\begin{array}{l}52 \text { for each } \\
\text { procedure } \\
\text { All: } 104\end{array}$ & $\begin{array}{l}\text { Dycal lining, } \\
\text { Cosmic Bond; Silar }\end{array}$ & Original & 11 & 86.5 & III & $\begin{array}{c}\text { A: } 78 \\
\text { B: } 82 \\
\text { All:: } 84^{\#}\end{array}$ & $\begin{array}{l}\text { 5/15: secondary caries } \\
\text { 3/15: fracture } \\
\text { 2/15: bulk discoloration }\end{array}$ & $\begin{array}{l}\text { None } \\
\text { (restorative } \\
\text { techniques) }\end{array}$ \\
\hline $\begin{array}{l}\text { Fukushima } \\
1993 \text { [5] }\end{array}$ & $\begin{array}{l}\text { University } \\
\text { Japan }\end{array}$ & $\mathrm{CCT}$ & $\begin{array}{c}\text { dental } \\
\text { students }\end{array}$ & - & - & $\begin{array}{l}\text { BP: } 46 \\
\text { CP: } 46 \\
\text { P10: } 52 \\
\text { All: } 144\end{array}$ & $\begin{array}{l}\text { each adhesive; } \\
\text { Bellfirm P (BP), } \\
\text { Clearfil posterior } \\
(\mathrm{CP}), \mathrm{P}-10(\mathrm{P} 10)\end{array}$ & - & 10 & 81 & I \& II & $\begin{array}{l}\text { BP: } 78 \\
\text { CP: } 73 \\
\text { P10: } 64 \\
\text { All: } 71\end{array}$ & $\begin{array}{l}\text { 11/34: pulpitis } \\
\text { 8/34: fracture } \\
\text { 5/34: new caries } \\
\text { 1/34: secondary caries }\end{array}$ & $\begin{array}{l}\text { None } \\
\text { (materials) }\end{array}$ \\
\hline
\end{tabular}

[ ]: reference number, PDC: public dental clinic (service), RCT: randomized controlled clinical trial, CCT: controlled clinical trial, PLS: prospective longitudinal study, -: no information, NCCLs: noncarious cervical lesions, EE: etched only the enamel, TE: etched both enamel and dentin, < >: number of restorations at final recall, *: age at the last examination (SD), **: mean age of 46 patients who attended the 8-year recall

\#: survival rates were estimated by the Kaplan-Meier method, life table analysis, or reading survival curves. ${ }^{\# \#}$ : resin composites were placed without an adhesive. 
Table 5 Ten-year survival rates of resin composite restorations obtained from retrospective survival analysis (\%)

\begin{tabular}{|c|c|c|c|c|c|c|c|c|c|c|c|c|}
\hline $\begin{array}{c}1^{\text {st }} \text { Author } \\
\text { (year) } \\
\text { [Ref.] }\end{array}$ & $\begin{array}{l}\text { Setting } \\
\text { Country }\end{array}$ & $\begin{array}{l}\text { Placement } \\
\text { period }\end{array}$ & $\begin{array}{l}\text { No. of } \\
\text { patients }\end{array}$ & $\begin{array}{l}\text { Patient age } \\
\text { mean }(\mathrm{SD}) \\
\text { and/or range }\end{array}$ & $\begin{array}{l}\text { No. of } \\
\text { operators }\end{array}$ & $\begin{array}{l}\text { No. of } \\
\text { restorations }\end{array}$ & Materials & Criteria" & Class & $\begin{array}{l}\text { Survival } \\
\text { rates }\end{array}$ & $\begin{array}{l}\text { Main reasons for } \\
\text { replacement }\end{array}$ & $\begin{array}{l}\text { Significant } \\
\text { factors }\end{array}$ \\
\hline $\begin{array}{l}\text { Aoyama } \\
\text { (2008) [31] }\end{array}$ & $\begin{array}{r}1 \text { GDP } \\
\text { Japan }\end{array}$ & 1991-2005 & 95 & $33.3(14.2)^{*}$ & $\begin{array}{l}\text { unknown } \\
\text { but many }\end{array}$ & 245 & - & - & I \& II & 60.4 & $\begin{array}{l}\text { 68/87: secondary } \\
\text { caries }\end{array}$ & $\begin{array}{l}\text { occlusal } \\
\text { status }\end{array}$ \\
\hline $\begin{array}{l}\text { Opdam } \\
\text { (2007) [30] }\end{array}$ & $\begin{array}{c}1 \text { GDP } \\
\text { Netherlands }\end{array}$ & 1988-1997 & 248 & $18-80$ & 2 & $\begin{array}{l}\text { TE: } 376 \\
\text { SW: } 82 \\
\text { Total: } 458\end{array}$ & $\begin{array}{l}\text { RMGI lining cement } \\
\text { and Clearfil Photo } \\
\text { Bond, Liner Bond } 1 \\
\text { combined with PA }\end{array}$ & - & II & $\begin{array}{l}\text { TE: } 88.1^{* * *} \\
\text { SW: } 70.5^{* *}\end{array}$ & $\begin{array}{l}\text { TE: } 26 / 43 \text { caries; } \\
\text { SW: } 11 / 34 \text { caries, } \\
\text { 18/34 fracture }\end{array}$ & $\begin{array}{l}\text { lining and } \\
\text { caries risk }\end{array}$ \\
\hline $\begin{array}{l}\text { Opdam } \\
\text { (2007) [29] }\end{array}$ & $\begin{array}{c}1 \text { GDP } \\
\text { Netherlands }\end{array}$ & 1990-1997 & 621 & - & 2 & 1955 & $\begin{array}{l}\text { Clearfil Liner Bond } 1 \\
\text { combined with PA }\end{array}$ & - & I \& II & 82.2 & $\begin{array}{l}\text { 98/259: caries } \\
\text { 37/259: fracture } \\
\text { 28/259: endodontics }\end{array}$ & $\begin{array}{l}\text { amount of } \\
\text { restored } \\
\text { surfaces }\end{array}$ \\
\hline $\begin{array}{l}\text { Kubo } \\
(2001) \text { [28] }\end{array}$ & $\begin{array}{l}\text { University } \\
\text { Japan }\end{array}$ & $1982-2000$ & 93 & $\begin{array}{c}45.4 \\
15-77\end{array}$ & $1^{\#}$ & $\begin{array}{c}\text { I }: 27 \\
\text { II: } 43 \\
\text { III: } 219 \\
\text { IV: } 17 \\
\text { V: } 217 \\
\text { Total: } 577\end{array}$ & $\begin{array}{l}\text { Kuraray products such } \\
\text { as New Bond, Photo } \\
\text { Bond, Liner Bond II, } \\
\text { SE Bond Photo; FII, } \\
\text { Photo A, Posterior, } \\
\text { AP-X }\end{array}$ & $\begin{array}{l}\text { modified } \\
\text { USPHS }\end{array}$ & $\begin{array}{c}\text { I \& II } \\
\text { All }\end{array}$ & $\begin{array}{l}83.0 \\
81.2\end{array}$ & $\begin{array}{l}\text { 50/76: unknown, } \\
\text { 9/76: pulpitis, } \\
\text { 8/76: loss }\end{array}$ & $\begin{array}{l}\text { cavity type, } \\
\text { adhesive } \\
\text { system }\end{array}$ \\
\hline $\begin{array}{l}\text { Smales } \\
\text { (1996) [26] }\end{array}$ & $\begin{array}{l}3 \text { GDPs } \\
\text { Australia }\end{array}$ & -1992 & 100 & 29.5 (14.6) & 20 & $\begin{array}{l}\text { III : } 284 \\
\text { IV: } 57 \\
\text { V : } 96\end{array}$ & - & - & $\begin{array}{l}\text { III } \\
\text { IV } \\
\text { V }\end{array}$ & $\begin{array}{l}72.0 \\
56.3 \\
69.9\end{array}$ & not clear & $\begin{array}{l}\text { None } \\
\text { (materials) }\end{array}$ \\
\hline $\begin{array}{l}\text { Nikaido }^{\dagger} \\
\text { (2007) [40] }\end{array}$ & $\begin{array}{l}\text { University } \\
\text { Japan }\end{array}$ & 1992 & 26 & $\begin{array}{c}60.4^{*} \\
31-79\end{array}$ & 9 & $\begin{array}{c}\text { I : } 5 \\
\text { II: } 6 \\
\text { III: } 10 \\
\text { IV:5 } \\
\text { V: } 32 \\
\text { Total: } 58\end{array}$ & $\begin{array}{l}\text { Clearfil Photo Bond, } \\
\text { Liner Bond System }\end{array}$ & $\begin{array}{l}\text { original } \\
\text { criteria }\end{array}$ & $\begin{array}{l}\text { I } \\
\text { II } \\
\text { III } \\
\text { IV } \\
\text { V } \\
\text { All }\end{array}$ & $\begin{array}{c}60.0 \\
66.7 \\
80.0 \\
0.0 \\
75.0 \\
\text { All: } 67.2\end{array}$ & $\begin{array}{l}\text { 11/16: not clear, } \\
\text { 2/16: pulpitis, } \\
\text { 1/16: fracture, } \\
\text { 1/16: discoloration }\end{array}$ & cavity type \\
\hline
\end{tabular}

GDP: general dental practice, *: age at the investigation, -: no information, TE: total-etch, SW: sandwich, RMGI: resin modified glass-ionomer (Vitrebond or GC lining), PA: phosphoric acid etching, **: survival rate at 9 years,

$"$ : criteria were not for replaced or retreated restorations but for examination at the last visit. ${ }^{\#}$ : most of the restorations were placed by one operator (author). ${ }^{\dagger}:$ survival rates were calculated by descriptive statistics. 
Table 5 (continued) Ten-year survival rates of resin composite restorations obtained from retrospective survival analysis (\%) continued

\begin{tabular}{|c|c|c|c|c|c|c|c|c|c|c|c|c|}
\hline $\begin{array}{c}1^{\text {st }} \text { Author } \\
\text { (year) } \\
\text { [Ref.] }\end{array}$ & $\begin{array}{l}\text { Setting } \\
\text { Country }\end{array}$ & $\begin{array}{l}\text { Placement } \\
\text { period }\end{array}$ & $\begin{array}{l}\text { No. of } \\
\text { patients }\end{array}$ & $\begin{array}{l}\text { Patient age } \\
\text { mean }(\mathrm{SD}) \\
\text { and/or range }\end{array}$ & $\begin{array}{c}\text { No. of } \\
\text { operators }\end{array}$ & $\begin{array}{l}\text { No. of } \\
\text { restorations }\end{array}$ & Materials & Criteria" & Class & $\begin{array}{l}\text { Survival } \\
\text { rates }\end{array}$ & $\begin{array}{l}\text { Main reasons for } \\
\text { replacement }\end{array}$ & $\begin{array}{l}\text { Significant } \\
\text { factors }\end{array}$ \\
\hline \multirow{3}{*}{$\begin{array}{l}\text { Kubo } \\
\text { (2008) [33] }\end{array}$} & \multirow{3}{*}{$\begin{array}{c}\text { University } \\
\text { Japan }\end{array}$} & 1982-2005 & 55 & $\begin{array}{c}50.5(15.3) \\
7-77\end{array}$ & $49^{\circ}$ & $\begin{array}{cc}\text { I: } & 28 \\
\text { II: } & 43 \\
\text { III: } & 70 \\
\text { V: } & 116 \\
\text { Total: } 257\end{array}$ & $\begin{array}{l}\text { conventional 2-step } \\
\text { total-etch (Clearfil } \\
\text { New Bond, Photo } \\
\text { Bond) and 2-step self- } \\
\text { etch (Clearfil Liner } \\
\text { Bond II, SE Bond) } \\
\text { systems }\end{array}$ & $\begin{array}{l}\text { modified } \\
\text { USPHS }\end{array}$ & $\begin{array}{l}\text { I } \\
\text { II } \\
\text { III } \\
\text { V }\end{array}$ & $\begin{array}{l}59.9 \\
55.1 \\
69.7 \\
61.9\end{array}$ & $\begin{array}{l}\text { Class I: caries } \\
\text { Class II: caries and } \\
\text { fracture } \\
\text { Class III: caries } \\
\text { Class V: loss and } \\
\text { caries }\end{array}$ & $\begin{array}{l}\text { risk of } \\
\text { retreatment }\end{array}$ \\
\hline & & 1995-2005 & 18 & $\begin{array}{c}53.7(21.4) \\
7-77\end{array}$ & $24^{\circ \circ}$ & $\begin{array}{l}\text { I III: } 28 \\
\text { V: } 38 \\
\text { Total: } 66\end{array}$ & $\begin{array}{l}\text { 2-step self-etch } \\
\text { systems (Clearfil } \\
\text { Liner Bond II, SE } \\
\text { Bond) }\end{array}$ & $\begin{array}{c}\text { modified } \\
\text { USPHS }\end{array}$ & $\begin{array}{c}\mathrm{I} \sim \mathrm{III} \\
\mathrm{V}\end{array}$ & $\begin{array}{l}61.1 \\
72.3\end{array}$ & $\begin{array}{l}\text { 33/102: caries } \\
\text { 24/102: fracture } \\
\text { 16/102: loss }\end{array}$ & \\
\hline & & $1995-2005^{\# \#}$ & 101 & $\begin{array}{c}55.7(12.8) \\
15-82\end{array}$ & 1 & $\begin{array}{c}\text { I : } 33 \\
\text { II: } 128 \\
\text { III: } 138 \\
\text { V: } 180 \\
\text { Total: } 479\end{array}$ & $\begin{array}{l}\text { conventional 2-step } \\
\text { total-etch (Clearfil } \\
\text { Photo Bond) and 2- } \\
\text { step self-etch } \\
\text { (Clearfil Liner Bond } \\
\text { II, SE Bond) systems }\end{array}$ & $\begin{array}{l}\text { modified } \\
\text { USPHS }\end{array}$ & $\begin{array}{l}\text { I } \\
\text { II } \\
\text { III } \\
\text { V }\end{array}$ & $\begin{array}{l}60.1 \\
89.7 \\
79.6 \\
89.3\end{array}$ & $\begin{array}{l}\text { 13/102: endodontics } \\
\text { Class I: fracture } \\
\text { Class II: fracture } \\
\text { and caries } \\
\text { Class III: caries } \\
\text { Class V: loss }\end{array}$ & $\begin{array}{l}\text { risk of } \\
\text { retreatment, } \\
\text { cavity type }\end{array}$ \\
\hline $\begin{array}{l}\text { Kubo } \\
(2006) \text { [32] }\end{array}$ & $\begin{array}{l}\text { University } \\
\text { Japan }\end{array}$ & $1982-2005$ & 123 & $\begin{array}{c}54.4(14.5) \\
10-82\end{array}$ & $50^{\#}$ & $\begin{array}{c}\text { I: } \quad 61 \\
\text { II: } 193 \\
\text { III: } 284 \\
\text { V }_{1}: 82 \\
\text { V }_{2}: 428 \\
\text { Total: } 1106\end{array}$ & $\begin{array}{l}\text { conventional 2-step } \\
\text { total-etch (Clearfil } \\
\text { Photo Bond) and 2- } \\
\text { step self-etch } \\
\text { (Clearfil Liner Bond } \\
\text { II, SE Bond) systems }\end{array}$ & $\begin{array}{l}\text { modified } \\
\text { USPHS }\end{array}$ & $\begin{array}{l}\text { I } \\
\text { II } \\
\text { III } \\
\mathrm{V}_{1} \\
\mathrm{~V}_{2}\end{array}$ & $\begin{array}{l}67.8 \\
73.1 \\
78.8 \\
56.4 \\
87.3^{\star}\end{array}$ & $\begin{array}{l}\text { 83/243: caries } \\
\text { 45/243: loss } \\
\text { 33/243: fracture }\end{array}$ & $\begin{array}{l}\text { adhesive } \\
\text { systems }\end{array}$ \\
\hline
\end{tabular}

": criteria were not for replaced or retreated restorations but for examination at the last visit.

$\circ: 43 \%$ of the restorations were placed by dentists with less experience ( $\leq 5$ years). $71 \%$ were placed by dentists without experience of studying adhesion of restorative materials.

${ }^{\circ}: 26 \%$ of the restorations were placed by dentists with less experience ( $\leq 5$ years). $65 \%$ were placed by dentists at other departments (Prosthodontics, Periodontics, Pedodontics, etc.)

\#\#: recall rate of the restorations placed by the author was $91 \%$ at the final examination.

$\mathrm{V}_{1}$ : Class V restored with conventional 2-step total etch systems, $\mathrm{V}_{2}$ : Class V restored with 2-step self-etch systems

: survival rate was estimated without 225 restorations which were involved in clinical trials. 
Table 6 The effect of patient, operator, materials and tooth factors on the longevity of resin composite restorations

\begin{tabular}{|c|c|c|c|c|}
\hline & Factor & Not significant & Tendency & Significant \\
\hline \multirow[t]{3}{*}{ Patient } & Gender & $\begin{array}{l}\text { Opdam [29], [30], Aoyama } \\
\text { [31], Kubo [32] }\end{array}$ & & \\
\hline & Age & $\begin{array}{l}\text { Opdam [29], [30], Aoyama } \\
\text { [31], Kubo [32],[33] }\end{array}$ & & Hawthorne [27] \\
\hline & $\begin{array}{l}\text { Risk: Caries and/or } \\
\text { occlusion }\end{array}$ & & Nordbø [10] & $\begin{array}{l}\text { Opdam [30], Aoyama [31], } \\
\text { Kubo [33] }\end{array}$ \\
\hline \multirow[t]{4}{*}{ Operator } & Experience & Opdam [29], Kubo [32] & & Hawthorne [27], Opdam [30] \\
\hline & Skill & & & Kubo [32],[33] \\
\hline & Specialty & Kubo [32] & & \\
\hline & Change of operator & & & Hawthorne [27] \\
\hline \multirow[t]{3}{*}{ Materials } & Adhesive & Mair [12], Ritter [24] & & Dijken [22], [23] \\
\hline & resin composite & $\begin{array}{l}\text { Collins [11]*, Mair [12]*, } \\
\text { Pallesen [17], Rodolpho [18], } \\
\text { Opdam [29] }\end{array}$ & Nordb $\varnothing[10]$ & Lundin [14] \\
\hline & Technique & $\begin{array}{l}\text { Qvist [6], Lindberg [20], } \\
\text { Wilder [25] }\end{array}$ & & Opdam [30] \\
\hline \multirow[t]{4}{*}{ Tooth } & Class & $\begin{array}{l}\text { Raskin [13], Lundin [14], } \\
\text { Kubo [32] }\end{array}$ & $\begin{array}{c}\text { Millar [9]**, } \\
\text { Nikaido [40]** }\end{array}$ & Rodolpho [18], Kubo [33] \\
\hline & Surfaces, size & Raskin [13], Lundin [14] & & $\begin{array}{l}\text { Rodolpho [18], } \\
\text { Opdam [29], [30] }\end{array}$ \\
\hline & Lesion characteristics & Wilder [25] & & \\
\hline & Tooth type & $\begin{array}{l}\text { Nordb } \varnothing[10], \text { Raskin [13], } \\
\text { Aoyama [31] }\end{array}$ & & $\begin{array}{l}\text { Dijken [15], Pallesen [17], } \\
\text { Rodolpho [18], Opdam [30] }\end{array}$ \\
\hline
\end{tabular}

Italic letters express a retrospective study

*: No difference in survival rates between materials was found, but significant differences in clinical performance, such as marginal adaptation, marginal discoloration and wear resistance, were observed.

**: Significant lower survival rates of Class IV compared to other class, but sample size was very small. 